\title{
MIASTA I MIESZCZANIE POLSKI CENTRALNEJ WOBEC NAPAŚCI KRZYŻACKIEJ W 1331 ROKU
}

\begin{abstract}
Streszczenie. W 1331 r. król Władysław I Łokietek toczył z zakonem krzyżackim ciężkie walki, które wypełniły ostatnie lata jego panowania. W czasie najazdów krzyżackich ucierpiały miasta, wsie, miejscowa ludność, grody oraz kościoły i klasztory. Kolejny władca, czyli Kazimierz III Wielki, postanowił wytoczyć Krzyżakom proces sądowy, by odzyskać utracone ziemie, tj. Pomorze Gdańskie, ziemie chełmińską i dobrzyńską, kasztelanię michałowską oraz Kujawy. Bogata dokumentacja procesowa znajduje się w wydawnictwie źródłowym Lites ac res gestae inter Polonos Ordinemque Cruciferorum. Oprócz książąt, rycerstwa i duchowieństwa zeznania w stosunku do konkretnych artykułów oskarżenia złożyli także mieszczanie, którzy wzięli aktywny udział w rozprawie. Zaświadczyli oni o agresji krzyżackiej, której sami niejednokrotnie doznali, wymieniając nie tylko bezpośrednie krzywdy, ale również zniszczenia poczynione w miastach i dobrach kościelnych. Analizując poszczególne świadectwa, można pokusić się więc o próbę rejestracji konkretnych strat materialnych w czasie zawieruchy wojennej. Niniejszy tekst jest ponadto przyczynkiem do dalszych badań nad udziałem mieszczan w procesie polsko-krzyżackim.
\end{abstract}

Słowa kluczowe: Polska, średniowiecze, Krzyżacy, wojny polsko-krzyżackie, miasta i mieszczanie w średniowieczu

Zaangażowanie w konflikty z zakonem krzyżackim wiązało się nie tylko z szeroko rozumianym wysiłkiem zbrojnym Królestwa Polskiego, ale także ze stratami demograficznymi, materialnymi oraz zachwianiem kondycji gospodarczej miast, co miało swoje wymierne przełożenie na całe państwo. Nabiera to szczególnej wymowy, jeśli wziąć pod uwagę fakt, iż niedawno zjednoczona pod berłem Władysława I Łokietka Polska prowadziła z Krzyżakami wojny, które wypełniły ostatnie lata panowania tego monarchy. Kolejny władca, czyli Kazimierz III 
Wielki, na początku 1338 r. wystosował pismo do Stolicy Apostolskiej w celu wszczęcia procesu sądowego przeciwko Zakonowi. Bullą z 4 maja 1338 r. papież Benedykt XII powołał sędziów w osobach Galharda de Carceribus oraz Piotra, kanonika w Annecy we Francji. Warto dodać, że w kolejnej bulli biskup Rzymu polecił wytoczenie odrębnego postępowania sądowego przeciwko Krzyżakom z powództwa arcybiskupa gnieźnieńskiego Janisława. To sprytne posunięcie strony polskiej miało w zamierzeniu przechylić szalę zwycięstwa w kwestii ostatecznego odzyskaniu Pomorza Gdańskiego, ziemi chełmińskiej, kasztelanii michałowskiej, ziemi dobrzyńskiej oraz Kujaw ${ }^{1}$. Pozew został wystawiony w październiku 1338 r. i miał być dostarczony Zakonowi bezpośrednio bądź odczytywany przez trzy niedziele lub święta w kościele parafialnym pw. św. Andrzeja i w kościele dominikańskim pw. św. Jana Chrzciciela w Łęczycy². Istotny z punktu widzenia podjętej problematyki jest również fakt, że publiczne wezwanie Krzyżaków przed sąd zostało ogłoszone w Łęczycy 22 listopada 1338 r. w kościele Dominikanów. Pozew został odczytany przez egzekutora Mikołaja, proboszcza kościoła pw. św. Krzyża w Opolu, na uroczystej mszy w obecności Władysława, księcia łęczyckiego i dobrzyńskiego oraz pozostałych urzędników jego dworu³

Celem niniejszego artykułu jest próba spojrzenia na trudny czas zmagań wojennych z perspektywy mieszczan Polski centralnej przez pryzmat ciekawej i bogatej dokumentacji procesu polsko-krzyżackiego, która znajduje się w wydawnictwie źródłowym Lites ac res gestae inter Polonos Ordinemque Cruciferorum ${ }^{4}$. W ramach sformułowanego w tytule problemu można wyróżnić dwa zasadnicze obszary podjętych dociekań. Po pierwsze, interesować nas będą miasta, które ucierpiały w czasie napaści wroga na centralne ziemie Królestwa Polskiego,

${ }^{1}$ Historia dyplomacji polskiej, t. 1: Potowa X w. - 1572 r., red. M. Biskup, Warszawa 1980, s. 249; J. Bieniak, Geneza procesu polsko-krzyżackiego z 1339 roku, „Acta Universitatis Nicolai Copernici. Historia XXIV, Nauki Humanistyczno-Społeczne” 1990, z. 204, s. 23; J. Wy ROZUMSKI, Kazimierz Wielki, Wrocław 2004, s. 71-73.

2 T. Grabarczy , A. Kowalska-Pietrzak, T. Nowak, Dzieje miasta do końca XVI wieku, [w:] Eęczyca. Dzieje miasta w średniowieczu i w XX wieku. Suplement do monografii miasta, red. J. Szy mczak, Łęczyca-Łódź 2003, s. 13.

${ }^{3}$ H. ChŁopocka, Procesy Polski z Zakonem krzyżackim w XIV wieku. Studium źródtoznawcze, Poznań 1967, s. 126; A. Szy mCZa Kowa, Urzędnicy tęczyccy i sieradzcy za panowania ostatnich książąt dzielnicowych, „Rocznik Łódzki” 1979, t. 25 (28), s. 134; J. Bienia K, Przebiegprocesu polsko-krzyżackiego z 1339 roku, „Pamiętnik Biblioteki Kórnickiej” 1993, z. 23, s. 13.

${ }^{4}$ Lites ac res gestae inter Polonos Ordinemque Cruciferorum, t. 1, wyd. I. ZAKrzewski, Poznań 1890 (dalej: Lites). 
o czym mówią zeznania poszczególnych świadków procesu (w niniejszym przyczynku skupiono się tylko na relacjach mieszczan) oraz zaangażowanie ośrodków miejskich w przedsięwzięciach antykrzyżackich, o czym szerzej w dalszej części artykułu. W kręgu naszej uwagi znajdują się również sylwetki mieszczan Polski centralnej, którzy wzięli aktywny udział we wspomnianej rozprawie sądowej.

Wydarzenia, które są głównym przedmiotem niniejszej analizy, stanowiły pokłosie kampanii wrześniowej z 1331 r., podjętej przez Krzyżaków, kiedy ich oddziały wyruszyły z ziemi chełmińskiej (12 września) i kierując się wzdłuż prawego brzegu Wisły, dotarły do Płocka, przekraczając rzekę, by następnie znaleźć się na obszarze Łęczyckiego i Sieradzkiego. Trasa pochodu wojsk nieprzyjaciela została zrekonstruowana przez Stanisława Zajączkowskiego. Siły wroga podążyły z Płocka w kierunku południowo-zachodnim, docierając do Koła nad Wartą i dalej maszerując prawym brzegiem Wisły w kierunku południowym, dotarły nad Chełmno, Sobótkę, Cichmianę, Orzeszków, Ostrowsko i Wielenin, by ostatecznie znaleźć się w arcybiskupim Uniejowie (18 września). Przemierzając wspomniany trakt, napastnicy postanowili wydzielić dwa mniejsze oddziały. Pierwszy z nich, liczący ok. 600 zbrojnych, ruszył na Szadek i Sieradz, z kolei drugi, nieco mniejszy, skierował się - na wysokości Sobótki - do odległej o ok. 25 km Łęczycy, stanowiącej wówczas miejsce koncentracji sił polskich ${ }^{5}$. Nie wdając się w szczegółowy opis działań zbrojnych, należy jedynie wspomnieć, że opisywana tutaj kampania zakończyła się 27 września 1331 r. słynną bitwą pod Płowcami ${ }^{6}$.

Zanim jednak przejdziemy do nieco bardziej szczegółowego omówienia interesującego nas etapu tych zmagań wojennych oraz ich skutków dla miast i mieszczan, zwróćmy uwagę na kwestię precyzyjnego określenia procesu w historiografii, gdyż najczęściej jest on określany przez historyków jako „warszawski”. Trzeba jednak podkreślić za Janem Szymczakiem, że należałoby go raczej nazwać „warszawsko-uniejowskim”, ponieważ spora część pracy sądu odbyła się w Uniejowie

5 S. ZająCZKowski, Polska a Zakon Krzyżacki w ostatnich latach Wtadystawa Eokietka, Lwów 1929, s. 226-227; M. Biskup, Wojny Polski z Zakonem Krzyżackim (1308-1521), Gdańsk 1993, s. 25; T. Jurek, Pierwsze wieki historii Łęczycy, [w:] Początki Łęczycy, red. R. Grygiel, T. Jurek, t. 3: W kregu historii i historii sztuki, Łódź 2014, s. 112.

${ }^{6}$ Szeroko na temat bitwy pisali: M. BISkup, Analiza bitwy pod Ptowcami i jej dziejowego znaczenia, „Ziemia Kujawska” 1963, t. 1, s. 73-105; T. Jurek, Uwagi o bitwie pod Ptowcami, „Ziemia Kujawska” 1993, t. 9, s. 77-99; IDEm, Postscriptum do „Uwagi o bitwie pod Ptowcami”, „Ziemia Kujawska” 1993, t. 9, s. 287-289; IDEM, O Ptowcach znowu stów kilka, „Ziemia Kujawska” 1995, t. 11, s. 143-145; P. STrzyż, Ptowce 1331, Warszawa 2009, s. 102-170. 


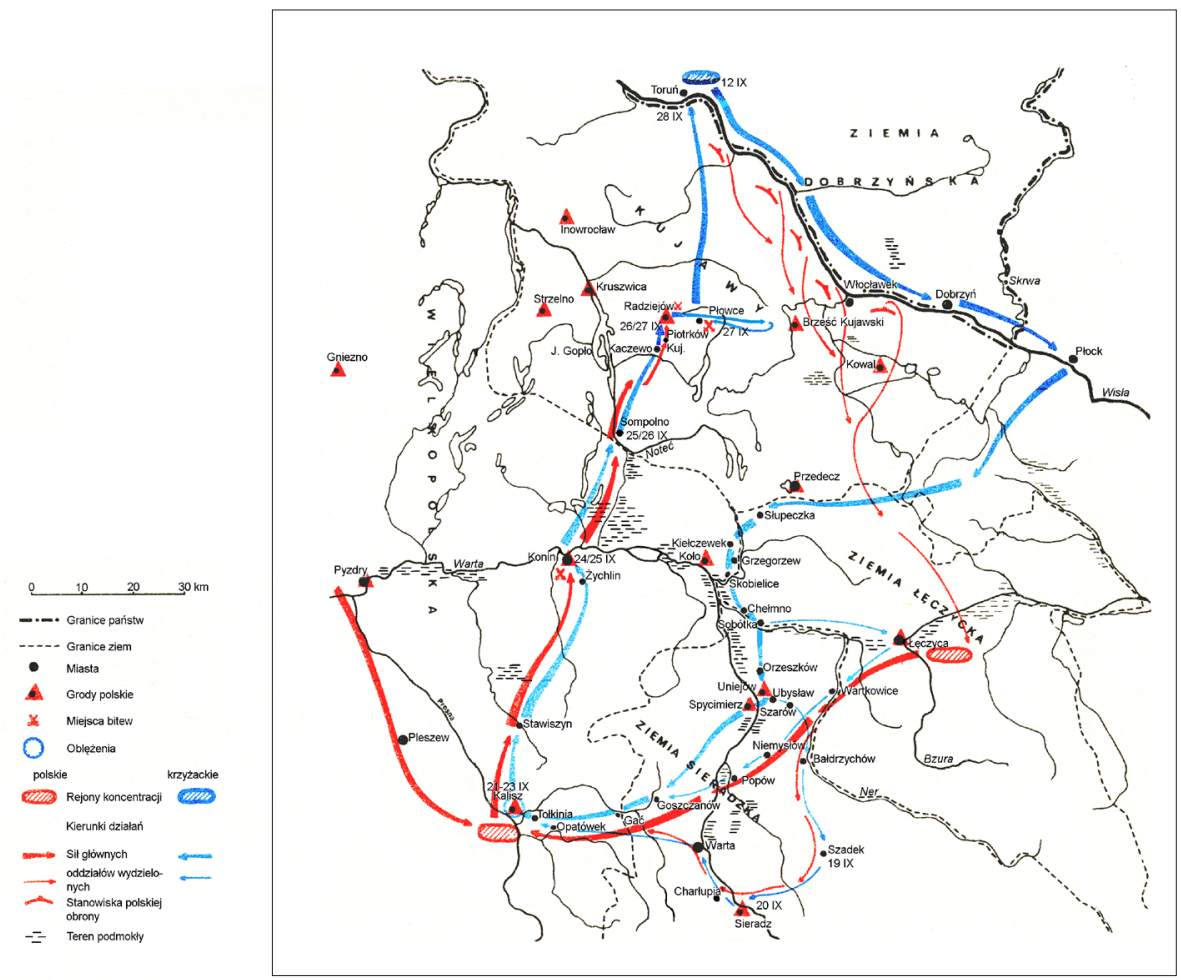

Ryc. 1. Najazd krzyżacki we wrześniu 1331 r.

(źródło: P. StRzyż, Płowce 1331, Warszawa 2009, s. 201)

w okresie od 20 lutego do 17 marca 1339 r. Ponadto 11 marca przybyło do tego miasta aż 72 świadków (Aneks II), wśród których znaleźli się książęta: Kazimierz inowrocławski oraz gniewkowski, a także Władysław Garbacz, książę dobrzyński i łęczycki. Do tego grona należy zaliczyć również wielu urzędników oraz duchowieństwo. Na wyjątkową wówczas rolę Uniejowa złożyły się niewątpliwie także inne czynniki. Miasto było siedzibą arcybiskupów gnieźnieńskich, których dobra ucierpiały w czasie najazdu w 1331 r. Wreszcie, położenie Uniejowa w centralnej części Królestwa Polskiego i solidne zaplecze miasta stwarzały możliwości pobytu uczestnikom sądu. Dodajmy, że wojna z 1331 r. nie nadwerężyła zanadto kondycji ekonomicznej miasta i jego mieszkańców, co również miało ogromne znaczenie ${ }^{7}$.

${ }^{7}$ J. Szymczak, Uniejów do schytku XVI wieku, [w:] Uniejów. Dzieje miasta, red. J. Szy mCZa K, Łódź-Uniejów 1995, s. 69. 
Chronologię pochodu poszczególnych oddziałów krzyżackich można zrekonstruować na podstawie kolejności wniesionych artykułów oskarżenia. Przypomnijmy zatem, że artykuł XXI został poświęcony Łęczycy i ziemi łęczyckiej, XXII dotyczył Uniejowa, XXIII - Sieradza, w XXIV wyliczono zaś straty poczynione w Warcie ${ }^{8}$, Szadku', Bałdrzychowie i Charłupi ${ }^{10}$.

Zeznania w sprawie Łęczycy złożyło ośmiu świadków ${ }^{11}$, w tym jeden mieszczanin. Relacje te mają - podobnie zresztą jak inne interesujące nas artykuły oskarżenia - różną wartość pod względem opisywanych wydarzeń, ale wszystkie zgodnie podkreślają skalę strat spowodowanych wrogim napadem na Łęczycę, tj. spalenie miasta i tamtejszych budowli sakralnych - kościoła parafialnego św. Andrzeja Apostoła, kościoła pw. św. Jana Chrzciciela i budynków należących do klasztoru Dominikanów ${ }^{12}$.

${ }^{8}$ Przywilej lokacyjny dla Warty wystawił w 1255 r. Kazimierz Konradowic, książę łęczycki i kujawski - Codex diplomaticus Poloniae, t. 2, cz. 1, wyd. L. Ryszczewski, A. Muczkowski, Warszawa 1848 (dalej: CDP), nr 64. Vide: S. Zajączkowski, S.M. Zajączkowski, Materiaty do stownika geograficzno-historycznego dawnych ziem tęczyckiej i sieradzkiej do 1400 roku, cz. 2, Łódź 1970, s. 164-165; A. BARTOSzewiCz, Wójtowie Warty w późnym średniowieczu, „Mazowieckie Studia Humanistyczne" 1996, nr 1, s. 197.

9 Najstarsza informacja o Szadku jako mieście pochodzi z 1295 r. - CDP, nr 157. Vide: S. ZaJĄCZKOWSKI, S.M. ZaJĄCZKOWSKI, op. cit., s. 131. Wszystkie osoby wywodzące się z Szadka i biorące udział w procesie wymienił T. Marszał, Szadkowski stownik biograficzny. Średniowiecze i renesans, Łódź 2012, s. 13, przyp. 19.

${ }^{10}$ Lites, s. 97.

${ }^{11}$ Listę zeznających otwierał książę Władysław Garbacz, który niewiele mógł powiedzieć o losach łęczyckiego grodu, gdyż na wieść o zbliżającym się wojsku nieprzyjaciela opuścił Łęczycę. Ponadto w sprawie Łęczycy zeznali: Paweł Ogon, w czasie napadu sprawujący urząd kasztelana łęczyckiego, a w 1339 r. składający zeznania już jako wojewoda łęczycki; Urban, podczaszy łęczycki; rycerz Jan z Kisielewa; Bogusław z Sandomierza, kantor łęczycki; rycerz Michał Łazęka z Łęczycy (znajdował się w oddziałach krzyżackich); Pielgrzym z Zajączkowa (również po stronie agresora). Vide: Lites, s. 287, 180, 199, 204-205, 272, 276, 310; Urzędnicy tęczyccy, sieradzcy i wieluńscy XIIIXV wieku. Spisy, oprac. J. Bieniak, A. Szymczakowa, red. A. Gąsiorowski, Wrocław 1985, s. 45, 81; J. SzyмсZAK, Wtadystaw Garbacz ostatni książę tęcycki (ok. 1327-1349, zm. 1351/1352), [w:] Tractu temporis. Ludzie - regiony - fakty. Ksiega dedykowana Profesorowi Tadeuszowi Nowakowi, red. T. Grabarczy K, A. Kowalska-Pietrzak, Łódź-Wieluń 2018, s. 118; idem, Łęczyccy Piastowie. Książęta, księżne i księżniczki w Łęczycy w XII-XIV wieku, Płock-Łęczyca 2019, s. 176.

12 Vide: J. Szymczar, Źródta pisane do dziejów średniowiecznej Łęczycy, [w:] Zapiski, wykopaliska, mapy. Źródta do dziejów Łęczycy. Materiaty z sesji naukowej w Łęczycy, dnia 26 kwietnia 2012 roku, red. L. SzTom PKA, M. ŻEmiga£A, ŁĘCZYCA 2012, s. 24-25; Ł. ĆwiKŁA, W sprawie agresji krzyżackiej na dobra kościelne w Eęczycy, Uniejowie i Sieradzu w 1331 r. w'świetle akt procesu polsko-krzyżackiego z 1339 r., „Łódzkie Studia Teologiczne” 2013, t. 22, s. 46-48. 
Mieszczanin szadkowski, Gocwin Rykalic ${ }^{13}$ oświadczył, że nie znajdował się w Łęczycy w momencie, gdy zaatakowali ją agresorzy, ale wie z całą pewnością, iż była przez nich spalona i obrabowana wraz z kościołami, opowiadali bowiem o tym uczestniczący w napadzie na Łęczycę Krzyżacy, którzy powrócili do Uniejowa, gdzie Rykalic stacjonował z resztą wojsk ${ }^{14}$.

Po splądrowaniu i zniszczeniu Łęczycy oddziały nieprzyjaciela ruszyły w kierunku głównej armii, która dotarła w międzyczasie do Uniejowa (18 września). Miasto oraz gród z załogą pod dowództwem Mikołaja, wojskiego sieradzkiego, zostały całkowicie zaskoczone. Istnieje duże prawdopodobieństwo, że ośrodek ten mógł stanowić w tym czasie kwaterę dla głównodowodzących wojskami krzyżackimi, tj. Ottona von Luterberga oraz Dietricha von Altenburg ${ }^{15}$. W sprawie Uniejowa zeznania złożyło dwunastu świadków, w tym dwóch mieszczan.

Znany nam już Gocwin Rykalic zeznał, że Krzyżacy wraz z wojskiem złupili i spalili Uniejów wraz z kościołami, tamtejszym grodem i wsiami. Gocwin widział to i był wówczas obecny, gdy wraz z wojskiem wkroczyli do miasta, złupili je oraz spalili, był bowiem w ich oddziałach i brał wraz z nimi do niewoli wielu szlachetnie urodzonych, których zdołali znaleźćc ${ }^{16}$.

Jan Prus ${ }^{17}$, wójt Uniejowa, był w mieście, gdy Krzyżacy wraz z wojskiem zaatakowali miasto i wkroczyli do niego. Kiedy ich zobaczył, w celu ratowania życia

13 Gocwin Rykalic wywodził się z kujawskiego Przypustu. Był bratem Jana Rykalica, nabywcy jednej z tamtejszej miejscowości, tj. Rozkidalina, który znajdował się w sąsiedztwie tego miasta. Rodzina Gocwina od kilku pokoleń zamieszkiwała Kujawy i pochodziła od Gocwina Derwinowica, odbiorcy dokumentu lokacyjnego dla Przypustu, wystawionego w 1274 r. przez Eufrozynę, matkę Władysława I Łokietka. Niestety nie są znane powody, dla których Gocwin Rykalic uczestniczył w wojnie z lat 13261332 po stronie Zakonu. Vide: J. BIENIAK, Wielkopolska, Kujawy, ziemie tęczycka i sieradzka wobec problemu zjednoczenia państwowego w latach 1300-1306, Wodzisław Śląski 2011, s. 44, przyp. 18.

${ }^{14}$ Lites, s. 272: „non fuit presens illo tunc in Lancicia, quando fuit spoliatum et crematum per dictos Cruciferos, sed bene scit pro certo quod fuit crematum et spoliatum cum ecclesiis (...) prout retulerunt sibi socii dicti exercitus qui fuerant missi per provincialem ad spoliandum et cremandum dictum locum de Lancicia”.

15 J. Szymcza K, Uniejów do schytku XVI wieku, s. 67.

16 Lites, s. 273: „magister et fratres Cruciferi cum eorum exercitu opidum Unyeow spoliarunt et cremaverunt cum ecclesiis et castro ibidem et cum villis (...) vidit et presens fuit quando dicti Cruciferi cum eorum exercitu dictum opidum intraverunt, spoliarunt et cremaverunt, quia de eorum exercitu errat unus, cum ecclesia ibidem, quia cum ipsi Cruciferi cepissent omnia bona que potuerunt invenire in dicto loco et extraxissent et secum asportassent".

${ }^{17}$ Jan Prus (Pruthenus) otrzymał w 1336 r. mlyn w Uniejowie od arcybiskupa gnieźnieńskiego Janisława. Jego przydomek zdaje się wskazywać na to, że musiał zapewne przybyć do Polski z któregoś 
uciekł do znajdującego się w pobliżu lasu i z wysokiego drzewa widział wzniecony przez wojsko ogień i dym. Zapytany, czy byli w Uniejowie jacyś zabici przez Krzyżaków, odpowiedział, że było ich od dwudziestu czterech do dwudziestu sześciu. Zapytany również o to, jak się nazywali, stwierdził, że byli to Hanco, Jan zwany Szular, Olrik, Klemens, Hińcza, Bertold. Krzyżacy zabrali również złoto, srebro, sukno i konie, a także szaty i kosztowności przybyszów, ponieważ w tym czasie w Uniejowie było wielu bogaczy oraz kupców. Z domu świadka uprowadzono zaś osiemnaście dużych koni oraz dwadzieścia jeden pociągowych ${ }^{18}$.

W odniesieniu do Sieradza zeznania złożyło w sumie dwanaście osób, w tym tylko jeden mieszczanin. Wszystkie zaangażowane osoby zgodnie donosiły o stratach i zniszczeniach, poczynionych w tamtym czasie w mieście.

Mincerz Paweł, civis seu opidanus de Siradia, potwierdził śmierć sześciu mieszczan (jeden z nich znany było jako Szczodrak) i stwierdził, że z zawieruchy wojennej uratowało się nie więcej niż dwanaście chałup ${ }^{19}$.

Pora teraz przyjrzeć się artykułowi XXIV oskarżenia, w stosunku do którego zeznało pięciu mieszczan.

Franciszek ${ }^{20}$, wójt i sędzia (advocatus et iudex) w Szadku, stwierdził, że mistrz i bracia zakonni wraz z potężnym wojskiem spalili i złupili miejscowości wraz

miast ziemi chełmińskiej lub często bywał w tamtych stronach. Przychylność Janisława względem Jana wydaje się stanowić przesłankę, zgodnie z którą należy wykluczyć jego tożsamość z bliżej nieokreślonym wójtem uniejowskim, który w 1326 r. wraz ze swym krewnym Konradem i innymi towarzyszami zranili kanonika tamtejszej kolegiaty, tj. Jana Radzisławica. Vide: J. BIENIAK, „Litterati” świeccy w procesie warszawskim z 1339 roku, [w:] Cultus et cognitio. Studia z dziejów średniowiecznej kultury, red. S.K. KuCZYŃsKi i in., Warszawa 1976, s. 105.

18 Lites, s. 225-226: „errat personaliter in dicto loco de Unyeow, quando dicti Cruciferi cum exercitu eorum ipsum hostiliter invaserunt et intraverunt (...) quando vidit eos, dedit fugam ad silvam ad evitandum mortem, et dum fuit in silva ascendit unam arborem altam de quaa vidit, quia prope est silva, ignem, flammas et fumum in dicto loco de Uneyow impositum per dictos Cruciferos et exercitum eorum (...) interrogatus, si fuerunt aliqui homines interfecti per dicto Cruciferos in dicto loco de Uneyow, dixit, quod sic, XXIV vel XXVI (...) interrogatus quomodo vocabantur, dixit quod unus vocabatur Hanco, alter Iohannes dictus Szular, alter Olricus, alter Clemens, alter Hincza, alter Bertholdus (...) acceperunt aurum, argentum, pannos et equos, et vestes et ornamenta hospiciorum, quia quam plures divites homines et mercatores erant illi tunc in dicto loco de Unyeow (...) acceperunt per dictos Cruciferos illo tunc XVIII equi magni et XXI eque seu iumenta et alia quam pluriba bona, vestes, ornamenta, boves et oves et alia innumerabilia bona”.

19 Ibidem, s. 370. Vide: J. Szymczak, Polityczne dzieje Sieradza do końca XVI wieku, [w:] Sieradz. Dzieje miasta do 1793 roku, t. 1, red. Z. ANusık, Łódź-Sieradz 2014, s. 62-63.

${ }^{20}$ Franciszek był pierwszym poświadczonym źródłowo wójtem w Szadku i został zaliczony w poczet mieszczan przez W. Sieradzana (Świadomość historyczna świadków w procesach 
z kościołami, o których mowa w tym artykule. Zapytany o źródło swojej wiedzy, odpowiedział, że nie był obecny w czasie napaści ani jej nie widział, ale później przybył do Szadku i ujrzał miasto doszczętnie spalone wraz z kościołem i swoim domem. Stwierdził również, że był następnie w innych miejscowościach i widział je całkowicie spalone. Zapytany również, skąd wie, że uczynili to Krzyżacy, odpowiedział, iż zostało to stwierdzone przez wielu ludzi z tych miejscowości, a później sam widział napastników w okolicy Uniejowa i w wielu innych miejscowościach w Królestwie, które nieprzyjaciele złupili i spalili. Podążał bowiem za nimi i ich wojskiem przez całe państwo od okolic Brześcia w ziemi kujawskiej, gdy król Władysław wraz ze swoim synem Kazimierzem prowadzili wojnę z Krzyżakami, a świadek widział wówczas, że byli to oni, ponieważ wielu ludzi zostało tam przez nich zabitych. Franciszek stwierdził ponadto, że wrogi najazd odbył się siedem lub osiem lat temu ${ }^{21}$.

Kuncza Kitel, mieszczanin z Szadka, podkreślił, że mistrz i bracia Zakonu z Prus wraz z wojskiem złupili i spalili wymienione miejscowości wraz z kościołami. Jego wiedza wiązała się z pobytem w tym czasie w Szadku, kiedy na własne oczy widział, jak wojsko krzyżackie wkroczyło do miasta, zrabowało je i spaliło wraz z kościołem, dzwonnicą wraz z dzwonem. Wspomniał również o śmierci

polsko-krzyżackich wXIV-XV wieku, Toruń 1993, s. 179 oraz aneks biograficzny). Alicja Szymczakowa (Kilka uwago wójtostwie i wójtach w Szadku wśredniowieczu, „Biuletyn Szadkowski” 2005, t. 5 , s. 33) podkreśliła, że na podstawie tylko tej jednej informacji źródłowej trudno precyzyjnie ustalić jego pochodzenie, gdyż określenia advocatus oraz iudex nie są predykatami stanowymi, a jedynie wskazują na pełnioną funkcję.

${ }^{21}$ Lites, s. 267: „magister et fratres Cruciferi cum eorum valido exercitu et hostiliter dicta loca seu opida in dicto articulo nominata spoliarunt et cremaverunt cum ecclesiis eorumdem, prout ponitur et est notorium ut dixit. Interrogatus, quomodo hoc scit, dixit, quod ipse testis qui loquitur non fuit presens quando dicti Cruciferi dixta opida spoliaverunt et cremaverunt cum exxlesiis prout ponitur, nec vidit dictos Cruciferos nec exercitum eorum illo tunc, sed postmodum, cum venisset ad dictum locum Szadek, invenit et vidit dictum locum totum crematum et incineratum cum ecclesia et domo sua (...) dixit eciam quod fuit postea in aliis locis et vidit illud idem, quod erant cremata penitus cum ecclesiis eorumdem (...) interrogatus, quomodo scit ipse testis qui loquitur quod Cruciferi de Prussia hoc fecissent, videlicet spoliassent et cremassent dicta loca, dixit, quia dicebatur sibi ab omnibus hominibus et mulieribus illorum locorum, et postea ipse testis qui loquitur vidit eos circa Uneyow et in aliis pluribus loci regni Polonie que spoliabant et cremabant, quia eos insequebatur a longe per totum regnum quosque circa civitatem Brestensem in dicta terra Cuyavie, ubi dominus Wladislaus rex quondam Polonie cum filio suo domino Kazimiro nunc rege et gente sua habuit bellum et conflictum cum dictis Cruciferis et eorum exercitu ipso teste qui loquitur vidente et presente, et tunc viderunt quod erant Cruciferi, quia infiniti ibi fuerunt interfecti per eos (...) interrogatus, quot anni sunt quod dicta opida fuerunt spoliata et cremata, dixit quod VII vel VIII anni sunt". 
w płomieniach dwóch osób przebywających w kościele. Zapytany o ich imiona, Kuncza Kitel odrzekł, że nie zapamiętał ich, ale inni ludzie dobrze znali ofiary, gdyż byli to dwaj bracia zakonni - niedawno przybyli do miasta. Zeznał ponadto, że napastnicy wlekli ze sobą kobiety i dziewczęta do swoich namiotów, a w czasie postoju dopuszczali się gwałtów i dręczyli je, jak usłyszał później, opowiedziały bowiem o tym w tajemnicy. On sam jednak tego nie widział, ponieważ wówczas uciekł, by uniknąć śmierci. Mimo to widział kobiety obnażane przez Krzyżaków w Szadku. Zapytany, skąd znał tożsamość napstników, odrzekł, że nosili czarny krzyż na białej szacie. Kuncza Kitel zeznał także, że działo się to około ośmiu lat temu, w czwartek. Indagowany o inne miejscowości wymienione w artykule, odpowiedział, że nie widział nieprzyjaciół ani ich wojska w czasie łupienia i palenia osad, ale po odwrocie wroga widział je całkowicie spalone, opustoszałe i zniszczone wraz z kościołami ${ }^{22}$.

Zolman, mieszczanin z Szadka, sołtys z Wilamowa, zeznał, że mistrz i bracia Zakonu złupili i spalili miejscowości wymienione w tym artykule wraz z kościołami. Zapytany, skąd o tym wie, odpowiedział, że był obecny i widział, jak nieprzyjaciele wraz z wojskiem wkroczyli do i najpierw zniszczyli wszystkie skrzynie znajdujące się w kościele, do których ludzie przynieśli swoje dobra w celu ich ochrony. Napastnicy zabrali ze sobą wszystko, co znaleźli w skrzyniach i kościele. Następnie złupili całą wieś i wszystkich przybyszów,

22 Ibidem, s. 267-268: „magister et fratres Cruciferi de Prussia cum eorum exercitu dicta loca nominata in dicto articulo spoliarunt et cremaverunt cum ecclesiis eorumdem, prout ponitur et est notorium ut dixit. Interrogatus qualiter scit hoc esse verum, dixit, quia ipse testis qui loquitur vidit et presens fuit in Szadek quando dicti Cruciferi cum eorum exercitu et vexillis et hostiliter venerunt ad dictum locum Szadek, quem spoliaverunt omnibus bonis cum ecclesia ibidem, et spoliis secum asportatis et raptis totam villam seu opidum incenderunt et cremaverunt cum ecclesia ibidem et campanile cum campanis ut dixit (...) dixit eciam quod duos homines interfecerunt in limine ecclesie, qui fuerunt ibidem cremati cum ecclesia ut dixit. Interrogatus, quomodo vocabantur, dixit quod non recordatur de nominibus eorum, sed alias bene noverat eos, quia errant duo fratres et de novo venerant ad dictum locum (...) dixit eciam quod trahebant et traxerunt mulieres et virgines ad tentoria sua et ad staciones eorum invitas et violenter, et eas opprimebant et violabant ut audivit postea ex relatu dictarum mulierum que hec dicebant occulte, sed ipse testis qui loquitur non vidit quod opprimerentur, quia fugiit tunc ad evitandum mortem ut dixit (...) oculis suis propriis vidit mulieres denudatas per dictos Cruciferos in dicto loco de Szadek (...) interrogatus, quomodo scit quod essent Cruciferi, dixit, quia habebant nigram crucem super alba veste (...) dixit quod VIII anni vel circa, et fuit factum feria quinta ut dixit (...) interrogatus de aliis locis et ecclesiis nominatis in presenti articulo dixit, quod non fuit presens nec vidit dicta loca cremata penitus cum ecclesiis eorumdem et spoliata et desolata per dictos Cruciferos". 
nie pomijając żadnych dóbr w tej miejscowości. Całkowicie spalili miejscowość i kościół, dzwonnicę i dzwon, tak, że nie pozostało nic w Szadku stanowiącym pogorzelisko. Krzyżacy zabili wówczas dwie osoby, których ciała spłonęły w kościele. Zolman, zapytany o to, jak się nazywały, odpowiedział, że nie zapamiętał ich imion, ponieważ byli to nowi przybysze. Zapytany również, czy były tam jakieś kobiety i dziewczęta, dręczone oraz pohańbione przez napastników, odrzekł, iż nie wie. Na pytanie, czy napastnicy obrabowali jakieś kobiety, odpowiedział, że tak, a niektóre nawet wielokrotnie. Zapytany, skąd wie, że byli to właśnie Krzyżacy, stwierdził, że nosili czarny krzyż na białej szacie. Ponadto powiedział, że działo się to około siedmiu lat temu. W sprawie innych miejscowości wymienionych w tym artykule zeznał, że widział je złupione i spalone wraz z kościołami, jednak nadmienił, że nie był obecny, gdy rycerze zakonni łupili i palili je, lecz później widział te miejscowości opustoszałe i spalone wraz ze świątyniami ${ }^{23}$.

Mieszczanin (krawiec) Arnald z Szadka stwierdził, że mistrz i bracia zakonu krzyżackiego wraz z wojskiem spalili i złupili miejscowości i kościoły wymienione w artykule. Zapytany o źródło swojej wiedzy, odpowiedział, że był świadkiem, gdy Krzyżacy z wojskiem wkroczyli do miasta. Wtargnęli najpierw do kościoła,

23 Ibidem, s. 268-269: „magister et fratres Cruciferi cum eorum exercitu loca nominata in presenti articulo spoliarunt et cremaverunt cum eorum ecclesiis ibidem (...) interrogatus de causa sciencie dixit, qui ipse testis qui loquitur vidit et presens fuit, quando dicti Cruciferi et exercitus eorum venerunt et intraverunt locum de Szadek violenter, et primo intrantes ecclesiam fregerunt omnes cistas quas in ea portaverunt homines dicti loci cum rebus suis ad salvandum eas (...) omnia que invenerunt in eis et infra ecclesiam acceperunt et spoliarunt et secum vias portaverunt (...) et postmodum totam villam et omnia hospicja, ita quod nichil dimiserunt boni in dicto loco, quia totum receperunt et secum portaverunt (...) et demum spoliata dicta ecclesia et dicto loco omnibus bonis et extractis de dicto loco per eos, totum locum et ecclesiam cum campanili et campanis incenderunt, combuxerunt et cremaverunt funditus, ita quod nichil remansit in dicto loco, quia totum fuit incineratum et crematum (...) et duos homines illo tunc dicti Cruciferi in dicto loco Szadek in limine ecclesie interfecerunt, qui postea fuerunt cremati ibidem quando ecclesia fuit cremata (...) interrogatus, quomodo vocabantur, dixit quod non recordatur de eorum nominibus, quia noviter venerant ad dictum locum (...) interrogatus, si fuerunt mulieres et virgines opresse vel violate per eos, dixit, quod nescit (...) interrogatus, si spoliaverunt mulieres, dixit quod sic, sicut digitum in manu, et alique fuerunt ter spoliate per dictos Cruciferos ut dixit (...) interrogatus, quomodo scit quod essent Cruciferi, dixit quia hebebant crucem nigram in alba veste (...) interrogatus, quot anni sunt, dixit quod VII anni vel circa (...) interrogatus de aliis locis nominatis in presenti articulo, si vidit ea spoliari et cremari per dictos Cruciferos et ecclesias eorum, dixit quod non fuit presens quando dicti Cruciferi ea spoliarunt et cremaverunt cum ecclesiis, sed postea fuit in eis et vidit et invenit dicta loca desolata et combusta et cremata cum ecclesiis eorumdem per dictos Cruciferos et exercitum eorum". 
rozbijając wszystkie skrzynie i pojemniki, w których znajdowały się rzeczy przyniesione przez ludzi w celu ich ochrony. Napastnicy spląd rowali wszystko, co było w skrzyniach i w kościele, zabierając łupy ze sobą. Zrabowali również wyposażenie ołtarza, a na koniec całą miejscowość, a wszystko, co udało im się znaleźć, zabrali ze sobą. Podłożyli ogień i spalili miasto doszczętnie wraz z kościołem, dzwonnicą i dzwonem. Arnald z Szadka stwierdził również, że zginęło dwóch mężczyzn, którzy spalili się w czasie pożaru świątyni, później znaleziono tam ich szczątki. Zapytany, jak się nazywali, odpowiedział, że byli to Janusz oraz Kuncza, bracia, krawcy, którzy niedawno przybyli do miasta. Na pytanie, czy najeźdźcy zgwałcili dziewczęta i czy dręczyli kobiety, mieszczanin odpowiedział, że nie widział tego. Stwierdził też, że słyszał o tym, iż Krzyżacy zabrali ze sobą żony rycerzy z Królestwa i zaprowadzili je do swoich namiotów w pobliżu Uniejowa, gdzie zostały one po trzech dniach zamordowane. Wspomniani rycerze zmarli później ze zmartwienia. Zapytany o to, skąd wie, że napastnicy to byli Krzyżakami, odpowiedział, że nie rozpoznał ich, ponieważ był wystraszony i natychmiast uciekł do lasu. Słyszał za to, że nosili oni czarny krzyż na białej szacie. Wspomniał również, że w kościele został spalony wizerunek Dziewicy Marii, który był wart pięć grzywien. Zaprzeczył, że widział inne spalone miejscowości, których dotyczył artykuł oskarżenia, gdyż nie było go, kiedy najeźdźcy poczynili tam szkody, ale później widział miejscowości wraz z kościołami, złupione, spalone i opustoszałe ${ }^{24}$.

${ }^{24}$ Ibidem, s. 269: „magister et fratres Curciferi cum eorum exercitu loca nominata in dicto articulo et ecclesias eorumdem cremaverunt et spoliarunt (...) interrogatus, quomodo hoc scit, dixit, quia ipse testis qui loquitur et presens fuit quando dicti Cruciferi cum exercitu eorum venerunt et intraverunt locum de Szadek, et intrantes primo ecclesiam, fregerunt archas et cistas omnes quas in ea portaverant homines dicti loci cum rebus eorum pro custodia (...) acceptis omnibus que erant in dictis cistis et infra ecclesiam, secum portaverunt et rapuerunt (...) et altaria eciam spoliaverunt ornamentis suis, et demum totum locum penitus et omnio omnibus que potuerunt invenire spoliaverunt, et facto spolio et secum asportato extra dictum locum (...) totum dictum locum incenderunt et cremaverunt penitus cum ecclesia ibidem et campanile cum campanis ut dixit (...) dixit eciam quod duos homines occiderunt in dicto loco dicti Cruciferi in limine ecclesie, qui fuerunt combuxti cum ecclesia, quia postea ossa eorum aliqua fuerunt inventa ibidem. Interrogatus, quomodo vocabantur, dixit quod unus vocabatur Ianussius et alter Cuncza, qui errant fratres et sartores et de novo venerant ad dictum locum ut dixit (...) interrogatus, si violaverunt virgines vel mulieres opresserunt, sed ipse testis qui loquitur hoc non vidit (...) dixit eciam se audivisse, quod dicti Cruciferi duxerunt et traxerunt violenter uxorem cuiusdam militis de Polonia ad stacionem seu tentoria eorum prope Unyeow, que mortua fuit post tres dies, et dictus miles mortuus fuit eciam pre dolore poste ut dixit (...) interrogatus, quomodo scit quod essent Cruciferi, dixit, quod nescit, quia nescit signa eorum nec advertit $\mathrm{d}$ ea, quia tantum timorem habebat, quod nesciebat bene quid videbat et statim fugiit ad 
Gocwin Rykalic, mieszczanin z Szadka, stwierdził, że mistrz i bracia Zakonu wraz z wojskiem złupili i spalili miejscowości oraz kościoły, wymienione w artykule oskarżenia. Zapytany o źródło swojej wiedzy, odpowiedział, że nie było go w tych miejscowościach, gdy Krzyżacy łupili je i palili wraz z kościołami, ale dobrze wiedział o tym fakcie, donosili bowiem o tym żołnierze, którzy zostali tam wysłani, a świadek znajdował się zaś w głównej armii wroga ${ }^{25}$.

Przywołane zeznania mają - co oczywiste - różną wartość pod względem szczegółowości opisu relacjonowanych wydarzeń. Ich wagę podnosi jednak dodatkowo fakt, iż niektórzy świadkowie znajdowali się w oddziałach wroga. Wszystkie relacje zgodnie określają straty poczynione w czasie napaści z września 1331 r., czyli spalenie miast, grodów, budynków, miejsc sakralnych i ograbienie - co celowo podkreślano - kościołów i klasztorów. W Szadku agresorzy spalili drewnianą farę, plebanię oraz dzwonnicę ${ }^{26}$. Także przedmioty liturgiczne w postaci kielichów mszalnych, ksiąg, szat oraz święte wizerunki dostały się w ręce napastników. Co istotne, w sposób dotkliwy ucierpiała miejscowa ludność, dla której był to niewątpliwie bardzo trudny czas.

Jak wynika z przeprowadzonej analizy, w procesie warszawsko-uniejowskim wzięło udział siedmiu mieszczan z terenu Polski centralnej na ogólną liczbę trzydziestu biorących udział w rozprawie sądowej przeciwko Zakonowi. Spośród nich tylko siedmiu znało łacinę $e^{27}$. Listę mieszczan warto uzupełnić jeszcze

silvam (...) audivit, quod portabant crucem nigram in alba veste super arma ut dixit (...) dixit eciam quod fuit cremata in dicta ecclesia dicti loci quedam ymago Virginis Marie, que constiterat $\mathrm{V}$ marchas (...) interrogatus si vidit cremari alia loca et ecclesias nominatas in presenti in presenti articulo per dictos Cruciferos, dixit quod non, quia non fuit ibi illo tunc, sed postea fuit in eis et vidit et invenit ea combuxta, spoliata et cremata et desolata cum ecclesiis eorumdem per dictos Cruciferos".

25 Ibidem, s. 273: „magister et fratres Cruciferi cum eorum exercitu spoliaverunt et cremaverunt loca et ecclesias in dictis articulis nominata (...) interrogatus quomodo hoc scit, dixit, quod ipse testis qui loquitur non fuit illo tunc in dictis locis, quando fuerunt spoliata et cremata, quia hoc retulerunt sibi socii sui dicti exercitus qui fuerunt missi ad dicta loca, quia ipse testis qui loquitur, illo tunc errat et ibat cum magno exercitu ut dixit".

26 T. Marszat, Szadek. Monografia miasta, Szadek 1995, s. 20.

27 Vide: A. BARtoszew ICZ, Mieszczanie „litterati” w polskim mieście późnego średniowiecza, „Kwartalnik Historyczny” 1994, R. 106, nr 4, s. 3. 
o mieszkańców Łęczycy. Byli to wójt starego miasta Krystan, nowego miasta Hanko, rajca Wawrzyniec, krawiec Janko, dwóch Teodoryków - rzeźnik i mincerz, kupiec Wilhelm, Mikołaj Piotrowski, Mikołaj Czarka oraz bliżej nieznany z nazwiska i profesji Wawrzyniec. Trzeba jednak podkreślić, że grupę tę wprawdzie wyłoniono do złożenia zeznań, ale - z różnych powodów - nie została ostatecznie przesłuchana ${ }^{28}$. Biorąc pod uwagę powyższe dane, należy stwierdzić, że bohaterowie niniejszego artykułu (Aneks I) stanowili 23\% ogółu wszystkich mieszczan, którzy aktywnie zaangażowali się w proces. Warto także wspomnieć, że Gocwin Rykalic i Jan Prus zaliczali się do ludzi wykształconych, posiadali bowiem umiejętność czytania i pisania po łacinie. Niniejszy artykuł można zatem potraktowaćjako przyczynek do pełnego opracowania kolejnego - obok rycerstwa i duchowieństwa - środowiska świadków w procesie polsko-krzyżackim ${ }^{29}$.

\section{ANEKS I}

\section{Mieszczanie Polski centralnej w procesie warszawsko-uniejowskim*}

Materiał zamieszczony w niniejszym aneksie sporządzono według następującego schematu:

1. Imię (nazwisko), data śmierci (post quem)

2. Miejsce pochodzenia

3. Rodzina

28 Lites, s. 75; H. ChєороскA, op. cit., s. 210, 212. Vide: J. Bienia K, Środowisko świadków procesu polsko-krzyżackiego z 1339 r., [w:] IDEM, Polskie rycerstwo średniowieczne. Wybór pism, Kraków 2002, 197-198.

29 Vide: J. Bienia K, Milites w procesie polsko-krzyżackim z 1339 roku, „Przegląd Historyczny” 1984, t. 75, z. 3, s. 503-514; IDEM, Udziat duchowieństwa zakonnego w procesie warszawsko-uniejowskim w 1339 roku, [w:] Klasztor w kulturze średniowiecznej Polski. Materiaty z ogólnopolskiej konferencji naukowej zorganizowanej w Dąbrowie Niemodlińskiej w dniach 4-6 XI 1993 przez Instytut Historii WSP w Opolu i Instytut Historyczny Uniwersytetu Wroctawskiego, red. A. PoBóg-LenARTOW ICZ, M. DERWICH, Opole 1995, s. 467-490.

* Niniejsze zestawienie obejmuje wszystkich mieszczan z terenu Polski centralnej, którzy wzięli udział w procesie. Do ich grona zaliczyliśmy także Franciszka, ówczesnego wójta w Szadku. Vide: przyp. 20. Aneks opracowano na podstawie Lites, passim oraz W. SieradzAN, op. cit., aneks biograficzny. 
4. Wykształcenie (litteratus, illiteratus)

5. Sprawowane urzędy i godności państwowe lub kościelne

6. Udział w procesie (miejsce, czas zaprzysiężenia i złożenia zeznania)

1

1. Arnald (Arnold), zm. po 19 marca 1339 r.

2. mieszczanin (krawiec) z Szadka

3. -

4. illiteratus

5. -

6. XXXIX świadek oskarżenia, zaprzysiężony i przesłuchany 2 marca $1339 \mathrm{r}$. w Uniejowie

\section{2}

1. Franciszek, zm. po 2 marca 1339 r.

2. mieszczanin z Szadka

3. -

4. illiteratus

5. wójt w Szadku (1339)

6. XXXVI świadek oskarżenia, zaprzysiężony i przesłuchany 2 marca 1339 r. w Uniejowie

3

1. Gocwin Rykalic, zm. 2 marca 1339 r.

2. mieszczanin z Szadka rodem z kujawskiego Przypustu

3. ojciec: Gocwin Derwinowic (?); brat: Jan Rykalic

4. litteratus

5. -

6. XL świadek oskarżenia, zaprzysiężony i przesłuchany 2 marca 1339 r. w Uniejowie

4

1. Jan zwany Prus (Pruthenus), zm. po 25 kwietnia $1341 \mathrm{r}$.

2. z Prus (?): mieszczanin uniejowski 
3. -

4. litteratus

5. wójt Uniejowa (1336 - 25 kwietnia 1341), wójt w Turku (1341)

6. XXIII świadek oskarżenia, zaprzysiężony 6 lutego 1339 r. w Warszawie, przesłuchany 20 lutego 1339 r. w Uniejowie

5

1. Kuncza Kitel, zm. po 2 marca 1339 r.

2. mieszczanin z Szadka

3. -

4. illiteratus

5. -

6. XXXVII świadek oskarżenia, zaprzysiężony i przesłuchany 2 marca $1339 \mathrm{r}$. w Uniejowie

6

1. Pawel, zm. po 15 kwietnia 1339 r.

2. mieszczanin z Sieradza (mincerz)

3. -

4. illiteratus

5. -

6. XCIX świadek oskarżenia, zaprzysiężony i przesłuchany 15 kwietnia 1339 r. w Sieradzu

7

1. Zolman, zm. po 2 marca 1339 r.

2. mieszczanin z Szadka

3. -

4. illiteratus

5. sołtys z Wilamowa (na wschód od Szadku) w 1339 r.

6. XXXVIII świadek oskarżenia, zaprzysiężony i przesłuchany 2 marca 1339 r. w Uniejowie 


\section{ANEKS II}

\section{Zaangażowanie miast Polski centralnej w proces warszawsko-uniejowski}

\begin{tabular}{|c|c|c|}
\hline Miasto & Liczba powolanych i zaprzysiężonych świadków & Data \\
\hline Łęczyca & 9 & 16 lutego 1339 \\
\hline Łęczyca & 2 & 17 lutego 1339 \\
\hline Łęczyca & 2 & 17 lutego 1339 \\
\hline Uniejów & 1 & 20 lutego 1339 \\
\hline Uniejów & 6 & 20 lutego 1339 \\
\hline Uniejów & 3 & 25 lutego 1339 \\
\hline Uniejów & 3 & 26 lutego 1339 \\
\hline Uniejów & 1 & 27 lutego 1339 \\
\hline Uniejów & 7 & 2 marca 1339 \\
\hline Uniejów & 72 & 11 marca 1339 \\
\hline Uniejów & 2 & 15 marca 1339 \\
\hline Sieradz & 7 & 15 kwietnia 1339 \\
\hline
\end{tabular}

Opracowanie własne, na podstawie: H. CнŁOPOCKA, op. cit., s. 133-134.

\section{BIBLIOGRAFIA}

\section{Źródła drukowane}

Codex diplomaticus Poloniae, t. 2, cz. 1, wyd. L. Ryszczewski, A. Muczkowski, Warszawa 1848.

Lites ac res gestae inter Polonos Ordinemque Cruciferorum, t. 1, wyd. I. Zakrzewski, Poznań 1890.

\section{Opracowania}

Bartoszewicz A., Mieszczanie „litterati” wpolskim mieście późnego średniowiecza, „Kwartalnik Historyczny" 1994, R. 106, nr 4, s. 3-19. 
Bartoszewicz A., Wójtowie Warty w późnym średniowieczu, „Mazowieckie Studia Humanistyczne" 1996, nr 1, s. 197-204.

Bieniak J., Geneza procesu polsko-krzyżackiego z 1339 roku, „Acta Universitatis Nicolai Copernici. Historia XXIV, Nauki Humanistyczno-Społeczne” 1990, z. 204, s. 23-50.

Bieniak J., „Litterati” 'swieccy w procesie warszawskim z 1339 roku, [w:] Cultus et cognitio. Studia z dziejów średniowiecznej kultury, red. S.K. Kuczyński i in., Warszawa 1976, s. 97-106.

Bieniak J., Milites w procesie polsko-krzyżackim z 1339 roku, „Przegląd Historyczny” 1984, t. 75, z. 3, s. 503-514.

Bieniak J., Przebieg procesu polsko-krzyżackiego z 1339 roku, „Pamiętnik Biblioteki Kórnickiej” 1993, z. 23, s. 5-22.

Bieniak J., Środowisko świadków procesu polsko-krzyżackiego z 1339 r., [w:] idem, Polskie rycerstwo średniowieczne. Wybór pism, Kraków 2002, s. 195-214.

Bieniak J., Udziat duchowieństwa zakonnego $w$ procesie warszawsko-uniejowskim w 1339 roku, [w:] Klasztor w kulturze średniowiecznej Polski. Materiaty z ogólnopolskiej konferencji naukowej zorganizowanej w Dąbrowie Niemodlińskiej w dniach 4-6 XI 1993 przez Instytut Historii WSP w Opolu i Instytut Historyczny Uniwersytetu Wroctawskiego, red. A. Pobóg-Lenartowicz, M. Derwich, Opole 1995, s. 467-490.

Bieniak J., Wielkopolska, Kujawy, ziemie tęczycka i sieradzka wobec problemu zjednoczenia państwowego w latach 1300-1306, Wodzisław Śląski 2011.

Biskup M., Analiza bitwy pod Ptowcami i jej dziejowego znaczenia, „Ziemia Kujawska” 1963 , t. 1, s. 73-105.

Biskup M., Wojny Polski z Zakonem Krzyżackim (1308-1521), Gdańsk 1993.

Chłopocka H., Procesy Polski z Zakonem krzyżackim w XIV wieku. Studium źródtoznawcze, Poznań 1967.

Ćwikła Ł., W sprawie agresji krzyżackiej na dobra kościelne w Łęczycy, Uniejowie i Sieradzu w 1331 r. w świetle akt procesu polsko-krzyżackiego z 1339 r., „Łódzkie Studia Teologiczne" 2013, t. 22, s. 45-51.

Grabarczyk T., Kowalska-Pietrzak A., Nowak T., Dzieje miasta do końca XVI wieku, [w:] Łęczyca. Dzieje miasta wśredniowieczu i wXX wieku. Suplement do monografii miasta, red. J. Szymczak, Łęczyca-Łódź 2003, s. 9-104.

Historia dyplomacji polskiej, red. M. Biskup, t. 1: Potowa Xw. - 1572 r., Warszawa 1980.

Jurek T., O Ptowcach znowu stów kilka, „Ziemia Kujawska” 1995, t. 11, s. 143-145.

Jurek T., Pierwsze wieki historii Łęczycy, [w:] Początki Łęczycy, red. R. Grygiel, T. Jurek, t. 3: W kreggu historii i historii sztuki, Łódź 2014, s. 7-196.

Jurek T., Postscriptum do „Uwagi o bitwie pod Ptowcami”, „Ziemia Kujawska” 1993, t. 9, s. 287-289.

Jurek T., Uwagi o bitwie pod Ptowcami, „Ziemia Kujawska” 1993, t. 9, s. 77-99.

Marszał T., Szadek. Monografia miasta, Szadek 1995.

Marszał T., Szadkowski stownik biograficzny. Średniowiecze i renesans, Łódź 2012. 
Sieradzan W., Świadomość historyczna świadków w procesach polsko-krzyżackich w XIV-XV wieku, Toruń 1993.

Strzyż P., Ptowce 1331, Warszawa 2009.

Szymczak J., Łęczyccy Piastowie. Ksią̇ęta, księżne i księżniczki w Łęczycy w XII-XIV wieku, Płock-Łęczyca 2019.

Szymczak J., Polityczne dzieje Sieradza do końca XVI wieku, [w:] Sieradz. Dzieje miasta do 1793 roku, t. 1, red. Z. Anusik, Łódź-Sieradz 2014, s. 39-79.

Szymczak J., Uniejów do schytku XVI wieku, [w:] Uniejów. Dzieje miasta, red. J. Szymczak, Łódź-Uniejów 1995, s. 95-107.

Szymczak J., Wtadystaw Garbacz ostatni ksiąze tęczycki (ok. 1327-1349, zm. 1351/1352), [w:] Tractu temporis. Ludzie - regiony - fakty. Ksiega dedykowana Profesorowi Tadeuszowi Nowakowi, red. T. Grabarczyk, A. Kowalska-Pietrzak, Łódź-Wieluń 2018, s. $105-128$.

Szymczak J., Źródta pisane do dziejów średniowiecznej Łęczycy, [w:] Zapiski, wykopaliska, mapy. Źródta do dziejów Łęczycy. Materiaty z sesji naukowej w Łęczycy dnia 26 kwietnia 2012 roku, red. L. Sztompka, M. Żemigała, Łęczyca 2012, s. 11-40.

Szymczakowa A., Kilka uwag o wójtostwie i wójtach w Szadku w średniowieczu, „Biuletyn Szadkowski” 2005, t. 5, s. 31-45.

Szymczakowa A., Urzędnicy tęczyccy i sieradzcy za panowania ostatnich książą dzielnicowych, „Rocznik Łódzki” 1979, t. 25 (28), s. 107-139.

Urzędnicy tęczyccy, sieradzcy i wieluńscy XIII-XV wieku. Spisy, oprac. J. Bieniak, A. Szymczakowa, red. A. Gąsiorowski, Wrocław 1985.

Wyrozumski J., Kazimierz Wielki, Wrocław 2004.

Zajączkowski S., Polska a Zakon Krzyżacki w ostatnich latach Wtadystawa Eokietka, Lwów 1929.

Zajączkowski S., Zajączkowski S.M., Materiaty do stownika geograficzno-historycznego dawnych ziem tęczyckiej i sieradzkiej do 1400 roku, cz. 2, Łódź 1970.

Łukasz Ćwikła

\section{TOWNS AND TOWNSPEOPLE OF CENTRAL POLAND AND THE TEUTONIC INVASION IN 1331}

Summary. In 1331 Władysław Łokietek was at war with the Teutonic Order, which filled the last years of his reign. During the Teutonic invasions many towns, villages, local people, forts, churches and monasteries suffered. The next ruler, i.e. Kazimierz Wielki, decided to open the lawsuit against the Teutonic Knights in order to regain the lost lands, Gdańsk Pomerania, the lands of Chełmno, Dobrzyń, the castellany of Michałów and Kujawy. Extensive procedural documentation can be found in the source publication Lites ac res gestae inter Polonos Ordinemque Cruciferorum. In addition to the princes, knights and clergy, testimony against specific articles 
was also made by the townspeople who actively participated in the trial. They testified to the aggression of the Teutonic Knights, which they experienced many times, emphasizing not only direct harm, but also the destruction of cities and church property. By analyzing individual testimonies, you can try to capture specific material losses during the turmoil of war. This text is also a contribution to further research on the participation of the townspeople in the Polish-Teutonic trial.

Keywords: Poland, the Middle Ages, the Teutonic Knights, Polish-Teutonic wars, towns and townspeople during the Middle Ages 